anthropology \& materialism

\section{Anthropology \& Materialism}

A Journal of Social Research

$2 \mid 2014$

The Persistence of Myth

\title{
'Between Marx and Fourier'
}

Le Monde, 31.05.1969

\section{Pierre Klossowski}

Translator. Andrew McGettigan

\section{(2) OpenEdition}

\section{Journals}

Electronic version

URL: http://journals.openedition.org/am/356

DOI: $10.4000 / a m .356$

ISSN: 2364-0480

\section{Publisher:}

CETCOPRA, CRASSH - Center for Research in the Arts Social Sciences and Humanities, Fakultät

Gestaltung - Universität der Künste Berlin

Electronic reference

Pierre Klossowski, «'Between Marx and Fourier' », Anthropology \& Materialism [Online], 2 | 2014, Online since 15 April 2014, connection on 19 April 2019. URL : http://journals.openedition.org/am/356 ; DOI : 10.4000/am.356

This text was automatically generated on 19 April 2019.

Tous droits réservés 


\title{
'Between Marx and Fourier'
}

Le Monde, 31.05.1969

\author{
Pierre Klossowski
}

Translation : Andrew McGettigan

1 I met Walter Benjamin in 1935 during one of the meetings of Contre-Attaque (CounterAttack) - as that ephemeral fusion of the groups of André Breton and Georges Bataille was known. Later he was an assiduous audience member of the College of Sociology - an outwards facing offshoot of the secret, closed group, Acéphale - (which had crystallised around Bataille following his rupture with Breton). From that time on, he sometimes attended our private little conclaves.

Disconcerted by the ambiguity of Acéphale's a-theology, Walter Benjamin presented to us objections deriving from his analysis of the intellectual evolution of the German bourgeoisie, namely that "raising the metaphysical and political stakes of the incommunicable" (in accordance with the antinomies of industrial capitalist society) would have prepared a psychic terrain favourable to Nazism. From there, he tried to apply his analysis to our own situation. Discretely, he wanted us to resist taking that "plunge"; despite the appearance of an irreducible incompatibility, we risked flirting with nothing less than "prefascist aestheticism". He clung to this interpretative schemastill strongly influenced by the theories of Lukács, in order to overcome his own discomfort, and he sought to enclose us within this kind of dilemma.

3 No agreement was possible on this point of his analysis, the presuppositions of which coincided in no way with the premises and earlier history of the successive groups formed by Breton and Bataille, in particular with that of Acephale. In return, we questioned him even more insistently regarding what we perceived to be his most authentic depth, that is, his personal version of a "phalansterial" renewal ${ }^{1}$. Sometimes he spoke to us of it as an "esotericism" both "erotic and artisanal" lying beneath his explicitly Marxist conceptions. The common ownership of the means of production would allow the abolished social classes to be replaced by a society reorganised in terms of affective classes. A liberated industrial production, instead of subjugating affectivity, would allow its forms to flourish and organise its exchanges, in the sense that work would be 
made the ally of avid desires, and would cease to be the punitive recompense for having them.

\section{BIBLIOGRAPHY}

Hollier, D. 1995. Le Collège de Sociologie. 1937-1939. Paris: Gallimard, 884-885.

\section{NOTES}

1. Communal life as envisaged by Fourier.

\section{ABSTRACTS}

Pierre Klossowski’s testimony on Walter Benjamin

Le témoignage de Pierre Klossowski sur Walter Benjamin

INDEX

Keywords: Klossowski Pierre, Benjamin Walter, Marx Karl, Fourier Charles, Collège de Sociologie, anthropological materialism

Mots-clés: Klossowski (Pierre), Benjamin (Walter), Marx (Karl), Fourier (Charles), Collège de Sociologie, matérialisme anthropologique 